\title{
Antecedent Affecting Chinese Ethnic Community Saving at Islamic Bank of North Sumatra
}

\author{
Hilma Harmen ${ }^{1}$, Adelina Lubis ${ }^{2}$, Aprinawati ${ }^{1}$, Lokot Muda Harahap ${ }^{1}$, \\ Riza Indriani ${ }^{1}$. \\ ${ }^{I}$ Faculty of Economics, Universitas Negeri Medan, Medan, Indonesia \\ ${ }^{2}$ Faculty of Economics and Business, Universitas Medan Area, Medan, Indonesia \\ ${ }^{*}$ Corresponding author.Email: hilmaharmen@unimed.ac.id
}

\begin{abstract}
This study aims to identify and analyze the factors that influence the ethnic Chinese community to save at Islamic banks in North Sumatra. The factors of service quality, promotion, and profit-sharing ratio are the chosen factors to determine the factors of the ethnic Chinese community-saving at Islamic banks. The types of data used in this study are primary data and secondary data. Primary data was obtained by distributing online questionnaires to Chinese customers in North Sumatra, while secondary data was obtained through literature studies, the internet, banks, and other media. The research sample was 261 respondents. The method of analysis used is a descriptive qualitative analysis using the SPSS version 22.0 program. The study results and discussion show that the factors of service quality, promotion, and profit-sharing ratio have been assessed as useful and attractive to respondents. Thus it can be concluded that these factors affect the Chinese community of North Sumatra to save in Islamic banks.
\end{abstract}

Keywords: Ethnic Chinese, Service Quality, Promotion, Profit Sharing Ratio

\section{INTRODUCTION}

Islamic banking has been described as one of the fastest-growing industries in the past three decades [43] and has received widespread acceptance in Islamic and non-Islamic countries [29]. The Islamic Financial Services Industry Stability Report 2018 indicated that the global Islamic Financial Services Industry (IFSI) total asset was valued at US $\$ 2.05 \mathrm{tn}$ as of the end of 2017 [26]. Given the bright prospects for the industry in these markets, it is likely that Islamic finance will continue to expand.

In Indonesia in June 2020, total Sharia financial assets (excluding Sharia stocks) reached IDR 1,496.05 trillion, and Islamic banking still shows positive growth despite a slowdown, especially in T.P.F. growth [35]. In a long-term perspective, the Islamic banking system's development is expected to create operational efficiency and have high competitiveness by adhering to Islamic values, playing a significant role in the national economic system, and improving the community's welfare. The development policy can be carried out by developing a network of offices in potential areas. Indonesia, where the majority of the population is Muslim, is a country with tremendous potential as a place for the development of sharia-based economic activities. Potential in this regard is seen from the resources and economic activities of a region and the pattern of attitudes of economic actors towards Islamic banking products and services.

However, the development of Islamic finance in Indonesia for Islamic finance's market share is only $9.63 \%$, and conventional finance $91.06 \%$ [35]. This situation did not occur in North Sumatra Province. The development of Islamic banking continues to develop. Banks - Islamic banks have started to open branches in various districts/cities in the province of North Sumatra. North Sumatra has a population of $14,526,549$. In terms of ethnicity, the population of North Sumatra is divided into Javanese 33.4 percent, Toba (22.3 percent), Mandailing ( 9.5 percent), Nias (7.1 percent), Malay (6.0 percent), Karo (5.5 percent), Angkola (4.1 percent), Chinese (2.7 percent), Minang (2.6 percent), Simalungun (2.4 percent), Aceh (1, 0 
percent), Pakpak (0.8 percent), and other tribes around 2.6 percent [16].

Based on these data, although the number of Chinese population in North Sumatra is small, the Chinese community's role is enormous in the economy. North Sumatra is a very strategic area for the economy, namely trading. Many traders in North Sumatra come of Chinese ethnicity. There are many types of goods and services that they buy and sell. This activity is visible in the trading center of North Sumatra, where the majority of traders come from Chinese ethnicity. The presence of Islamic banking in North Sumatra is undoubtedly conducive to the smooth running of economic transactions. Islamic banking products and services for the North Sumatra Tioghoa community will help them run their business.

A research conducted by Business Times, 2008, as cited in [1]. The favorable attitude and perception of non-Muslims towards Islamic banking in recent years is evidenced by a steady increased in the number of non-Muslim users of Islamic banking services and accounted for half of some of the Malaysian Islamic banks' customers. Islamic home financing and Islamic insurance or Takaful were among the Islamic banking products, which had drawn considerable interest from Malaysia's ethnic Chinese and Indian minorities.

It is, therefore, crucial for the Islamic banking sector to further tap the non-Muslim market and to create loyalty among non-Muslim customers to continue adopting Islamic banking products and services. Critical to this objective is establishing the key factors, which influence non-Muslim loyalty in adopting Islamic banking products and services. Based on the literature, the factors considered for this research are comprised of service quality, promotion, and profit sharing ratio.

\section{LITERATURE REVIEW}

\subsection{Islamic banking}

The Islamic banking philosophies are based on two basic principles that are the sharing of profit and loss and, significantly, the prohibition of the collection and payment of interest (Riba), as well as other activities that involve gambling (Maysir) and speculative trading (Gharar). Islamic banking is set out in accordance with the Sharia law, which is enshrined in the Qur'an, and the Sunna. Today, these principles form the basis of contemporary Islamic banking's range of Islamic financial products. The financial institutions providing a great deal of flexibility, creativity and choice with the offering of various products using various Islamic financial concepts such as ijarah (leasing), mudharabah (profit sharing), Musharakah (partnership), Murabahah (price deferred sale contract), Salam (object deferred sale contract) and Istisna (object and price sale contract) [28]. These principles are also supported by Islamic banking's core values. The appearance of the Islamic banking system has provided a new aspect of the current economic models [24].

The key principles in the Islamic banking system emphasize the need of sharing the risk, equity and stakes with the customers. The sharing aspect as the main requirement in the Islamic banking system suggests that the outcome of a project, whether it is profitable or otherwise, will be shared in an equitable manner [22]. The essence of Islamic principles is to achieve a fair distribution of wealth. The main aim of the Islamic banking system is to shield the benefits and interests of all parties who are involved in the economic transaction and to promote the welfare of the whole society as well [23].

\subsection{Service Quality}

Service quality is the outcome of a comparison made by a customer between the expectations of a product or service and the perception of the performance of the service received [36]. If any companies can deliver a high-quality service, the companies can retain their existing customers, attract new customers [25] and contribute to the market share [31]. Consequently, delivering high service quality is the primary factor to ensure business success [2].

The subject of service quality remains a critical point for all service industries in maintaining a competitive advantage in the marketplace. In fact, various service industries such as hotels, banking and non-banking financial institutions, insurance, travel, healthcare, education and local government agents strive to increase service quality, satisfy their customer and improve their profits [45]. Although it is not easy to set a universal standard of service quality scale, Parasuraman et al. [36] proposed a five subdimensions of service quality - reliability, tangibles, responsiveness, assurance and empathy - which is well-known as the SERVQUAL model. Then, the SERVQUAL model has been widely acknowledged to measure service quality in some researches setting such as healthcare, dental school patient clinic, business school placement centre, large retail chains, banking, dry cleaning and fast food restaurants [20]. Service quality in the Islamic banking industry Essential success and survival for every single business is the ability to deliver a high quality service to customers, and Islamic banks are no an exception to 
this [3]. The Islamic banking industry generally is facing a highly competitive business. Islamic banks are not only competing with other Islamic banks but also with the conventional banks, which are already well-established related to customers and market share [11]. Both Islamic and conventional banks that are financial service systems offer mostly similar products. Therefore, the banks can distinguish themselves by improved service quality, which is critical for boosting their market shares [40]. Islamic banking can be distinguished from conventional banking on three crucial grounds, namely, no earning of extra interest (Riba); no interest rates and practicing Islamic principles in business activity. Then, those three fundamental characteristics should be considered in measuring their service quality. In response to the unique characteristics, Othman and Owen [34] developed a CARTER model to measure service quality towards customer satisfaction in the Islamic banking sector. The model consists of five dimensions, namely, compliance, assurance, reliability, tangible, empathy and responsiveness. Compliance is the ability to follow Islamic principles when applying the Islamic banking business operations [34; 30]. It means all products or services developed and offered by Islamic banks should adhere to Islamic law.

Also, the entire business transaction should use the profit-sharing system and prohibit interest on funding and lending. Ullah [42] stated that several Islamic banks cannot comprehensively comply with Islamic law due to systemic factors such as economic system, government regulations, lack of research and development. However, Amin and Isa [4] asserted that Islamic banks should always improve the relationship of customers based on customer trust towards the principles of Islamic compliance. In previous empirical studies, compliance is found to be one of the most significant service quality determinants in the Islamic banking $[34 ; 40 ; 17 ; 38]$.

Assurance is the knowledge and courtesy of Islamic banking staffs and their verbal and written communication ability to deliver trust and confidence to their customers [34]. Therefore, excellent service quality requires staffs of Islamic banks to be polite with customers, skillful, competent, work on providing suitable financial advice and have easy access to customer account information [30]. Also, assurance becomes the essential dimension of service quality in satisfying customers of Islamic banking [39; 30]. Reliability is the ability to offer the promised service, dependability and accuracy to the Islamic banking customers [34]. Specifically, the speed of transaction is the most pivotal item influencing customer satisfaction in the banking industry [5].
Then, reliability makes an Islamic bank more efficient and positively reflects on the level of customer satisfaction [30]. Also, [4] and [33] found that reliability to be the most influential dimension perceived by Islamic banking customers. Tangible is associated with the appearance of physical facilities, equipment, personnel and communication material [34]. [30] proposed that tangible covers convenience of location, the design of physical facilities, materials and use of communication equipment. Also, service quality could perform well in Islamic banking when is supported by the element of tangibility [37]. Finally, tangible is a significant aspect of Islamic banking, which leads to customer satisfaction [6]. Empathy represents caring, individualised attention of the Islamic bank to its customers [34]. This dimension is the profiles of Islamic banks' staff, which can offer customised attention to individual customers. It is beneficial for Islamic banks to build intimacy between its staffs and customers. Empathy has been proved as a substantial dimension of service quality in Islamic banking that results in customers satisfaction $[6 ; 37$; 39].

Responsiveness embodies the willingness to help customers and provide prompt service [34]. [30] stated that fast and efficient frontliner staffs, the availability of banks' branches and A.T.M. are all examples of good responsiveness. Responsiveness is an essential element that must be considered by Islamic bank to improve the level of its customer satisfaction. That five-dimension of the CARTER model is the extension of the SERVQUAL model proposed by [36]. However, because the model lacks the dimension that measures the level of cultural aspects related to religion, Othman and Owen [34] developed a CARTER model that covers a lack of the SERVQUAL model by adding the dimension of compliance. At this point, we will assess whether the dimensions of the CARTER model is a significant model in shaping service quality in the context of the Indonesia Islamic banking. Then, here is the first research hypothesis:

\section{H1: Service quality has a positive and significant effect on interest in saving at Islamic banks in North Sumatra}

\subsection{Profit-Loss Sharing}

Profit-loss sharing ratio is fundamentally affected by market power [7]. Financing under profit-loss sharing would be increasing banking market value and maximizing shareholder return [8]. When banks can make the differentiation of product, market share and concentration will be greater so that they are able to operate their business more efficiently, leading profitability into higher value. This principle builds 
trust in people that banks are fair to manage fund. Mode of financing offered by banks based on mudharabah is that banks give investment and working capital, and then customer as a steward is assigned to build a business. The profit will be shared on the basis of initial agreement, and if the loss occurs, it will be charged by banks, thus leading to the following hypothesis:

H2: Profit Loss Sharing has a positive and significant effect on interest in saving at Islamic banks in North Sumatra

\subsection{Promotional Strategies}

Promotion is one of the 4Ps (product, price, promotion and place) of the marketing mix and that includes various tools such as: advertising, personal selling, direct marketing, public relations and so on. Promotion refers to the set of activities that communicate the merits of a product, service or brand to persuade target customers to buy it. It is a way of attracting, inducing and creating awareness among the people to initiate the purchase. Furthermore, promotion is considered as one of the means used to spread and to increase the market share of the organization by increasing its competition against similar organizations in the market. Attractive promotional activities facilitate potential market penetration; however, they must work within the boundaries of the marketing budget. Increasing customer demands, together with continuous growth in competition, are compelling the financial institutions to adopt new competitive and innovative ways to take the lead in the market place in the form of a loyal customer-base. According to Charles and Kumar [18], the operation of the banking sector is expected to be more dynamic and competitive with its escalating deregulation, liberalization and globalization.

Studies show that the aggressive and intensive marketing strategies adopted by all financial institutions in the banking sector have resulted in the decline of customer loyalty. Thus, retaining the loyalty of existing customers while attracting new customers has become of paramount importance. Businesses need to inform customers of the products and services they provide to facilitate the firm's survival in the very competitive business environment. In addition, effective communication with customers is vital to ensure that the business generates sales and profits [9], thus leading to the following hypothesis:

\section{H3: Promotional strategies has a positive and significant effect on interest in saving at Islamic banks in North Sumatra}

\section{METHODOLOGY}

The types of data used in this research are primary data and secondary data. Data collection techniques in this study are through questionnaires, interviews, observation, and library research. The population of this study was 392,216 respondents. According to [41], the sample is part of the population's number and characteristics. The sample size is determined using the Slovin formula, which aims to determine the number of representative samples based on the population. The number of research samples was 261 respondents, namely customers who save at Sharia Bank North Sumatra, namely Bank North Sumatra Syariah, Bank Mandiri Syariah, Bank B.R.I. Syariah.

The analytical method used is descriptive qualitative, namely the analysis method by collecting data systematically, analyzing and interpreting the data through descriptions to get a conclusion. Then with the Deductive analysis method, drawing logical conclusions based on theories that have been accepted as a general truth. Data processing and data analysis, the author, performs data processing using the SPSS (Statistic Product and Services Solution) version 22.0 program. The data analysis method used by the writer in this research is the descriptive exploratory analysis method, which aims to describe a situation or phenomenon in which the data that has been obtained is analyzed by describing a situation or a phenomenon, where the data that has been obtained is analyzed using tabulation, frequency, and crosstabulation. (cross tab), and images (graphics).

\section{RESULTS}

\subsection{Respondents' Profile}

The respondents of this research are the Chinese people who save at the Islamic Bank of North Sumatra. Customers who become respondents are asked questions in the form of an online questionnaire and the answers to these questions are presented in the form of tables, graphs, frequencies, images and cross tabs.

The results on characteristics of the respondents are presented in Table 1. In terms of gender, 52,5 per cent of the respondents were males and 47.5 per cent were females, implying an approximately even gender distribution. In addition, 12.3 per cent of the respondents were $<25$ and below, 56,7 per cent were 
between 25 and 35 years, while 38,3 per cent were 46-55 years and 2,7 per cent were $>56$, indicating the dominance of relatively younger population. In terms of education, about 47.5 per cent of them had pre-higher education (such as senior high school) and 52.5 per cent had higher education (Diploma/Higher Diploma and degrees). About 1,9 per cent of the respondents earned monthly income below $\mathrm{Rp}$. 1.000.000-Rp. 2.000.000, 4,5 per cent of the respondents earned monthly income below $\mathrm{Rp}$. 2.000.000 - Rp.3.000.000, 34,9 per cent of the respondents earned monthly income below $\mathrm{Rp}$. $3.000 .000-\mathrm{Rp} 4.000 .000$, 58,7 per cent of the respondents earned monthly income below > Rp. 4.000.000.

Table 1. Respondents' profile $(\mathrm{n}=261) \mathbf{5}$.

\begin{tabular}{cccc}
\hline Variable & Category & No. & $\mathbf{( \% )}$ \\
\hline Gender & Male & 137 & 52,5 \\
\hline Age & Female & 124 & 47,5 \\
\hline & $<25$ & 32 & 12,3 \\
\hline & $25-35$ & 148 & 56,7 \\
\hline Education & $46-55$ & 74 & 28,3 \\
\hline & $>56$ & 7 & 2,7 \\
\hline Income & Pre-higher education & 94 & 36,1 \\
\hline & Rp.1.000.000-Rp.2.000.000 & 5 & 167,9 \\
\hline & Rp.2.000.000- Rp.3.000.000 & 12 & 4,5 \\
\hline & Rp.3.000.000- Rp.4.000.000 & 91 & 34,9 \\
\hline & $>$ Rp.4.000.000 & 153 & 58,7 \\
\hline
\end{tabular}

\section{DISCUSSION OF RESULTS}

\subsection{Service Quality in The Islamic Banking}

Essential success and survival for every single business is the ability to deliver a highquality service to customers, and Islamic banks are no an exception to this [3]. The Islamic banking industry generally is facing a highly competitive business. Islamic banks are not only competing with other Islamic banks but also with the conventional banks, which are already well-established related to customers and market share [11]. Both Islamic and conventional banks that are financial service systems offer mostly similar products. Therefore, the banks can distinguish themselves by improved service quality, which is critical for boosting their market shares [40]. Service quality is measured from several aspects: tangible, reliability, responsiveness, assurance, and empathy.

\subsubsection{Tangible}

- The condition of the building and the cleanliness of the room and the beauty of the office interior

The frequency tabulation data shows the respondent's response about the condition of the building and the cleanliness of the room as well as the beauty of the interior of the Islamic bank office that 136 respondents or $52.1 \%$ stated that the condition of the building and the cleanliness of the room and the beauty of the office interior was excellent. A total of 112 respondents, or $42.9 \%$, answered satisfactorily, then ten respondents or $3.8 \%$ answered quite well, and three respondents or $1.2 \%$ answered poorly. Thus, the condition of Islamic bank buildings in North Sumatra is by customer expectations; namely, the building's condition is in good condition with cleanliness and beauty of the interior of the office space that is well ordered.Tangible is associated with the appearance of physical facilities, equipment, personnel and communication material [34]. Janahi and Almubarak [30] proposed that tangible covers convenience of location, the design of physical facilities, materials and use of communication equipment. Also, service quality could perform well in Islamic banking when is supported by the element of tangibility [37]. Finally, tangible is a significant aspect of Islamic banking, which leads to customer satisfaction [6]

\subsubsection{Reliability}

- Clarity of information explained by employees about Islamic bank products

Based on the frequency tabulation data, it shows that the clarity of information given by employees about Islamic savings products is as many as 50 respondents or $19.2 \%$ said it was excellent, as many as 125 respondents or $47.9 \%$ said it was good, then 82 respondents or $31.4 \%$ said it was enough. Right, and four respondents, or $1.5 \%$, said it was not good. Thus it can be concluded that employees of Islamic banks in North Sumatra are good at explaining Islamic savings products so that customers can understand and understand savings products that suit customer needs.

Reliability is the ability to offer the promised service, dependability and accuracy to the Islamic banking customers [34]. Specifically, the speed of transaction is the most pivotal item influencing customer satisfaction in the banking industry [5]. Then, reliability makes an Islamic bank more efficient and positively reflects on the level of customer satisfaction [30]. Also, Amin and Isa [4] and Osman et al. [33] found that reliability to be the most influential dimension perceived by Islamic banking customers. 


\subsubsection{Responsiveness}

- Speed and accuracy in depositing funds

As a professional employee, the employee must provide comfort and a good impression to a prospective customer, which can be demonstrated by a quick and precise attitude in opening prospective customer savings. The frequency tabulation data showed that 73 respondents, or $28.0 \%$ stated it was excellent based on the research results. The excellent assessment was $40.7 \%$, 22.2\% good enough and $9.1 \%$ said it was not good. Thus, it can be concluded that Islamic banks' employees are good at showing speed and accuracy in opening a savings account.

Responsiveness embodies the willingness to help customers and provide prompt service [34]. [30] stated that fast and efficient frontliner staffs, the availability of banks' branches and A.T.M. are all examples of good responsiveness. Responsiveness is an essential element that must be considered by Islamic bank to improve the level of its customer satisfaction.

\subsubsection{Assurance}

- The ability of employees to solve customer problems

The frequency tabulation data shows that as many as 63 respondents or $24.2 \%$ stated that it was excellent, then 64 respondents or $64 \%$ said that good, the assessment was quite fair as many as 89 respondents or $34.0 \%$ said it was quite good. As many as 45 respondents or $17,2 \%$ said it was not good. Thus, it can be concluded that the ability of employees to solve customer problems is quite good.

Assurance is the knowledge and courtesy of Islamic banking staffs and their verbal and written communication ability to deliver trust and confidence to their customers [34]. Therefore, excellent service quality requires staffs of Islamic banks to be polite with customers, skillful, competent, work on providing suitable financial advice and have easy access to customer account information [30]. Also, assurance becomes the essential dimension of service quality in satisfying customers of Islamic banking [39; 30]

\subsubsection{Empathy}

- Employees pay individual attention to customer complaints

An employee must treat the customer fairly, with no difference in the background of the customer. Based on the results of the frequency tabulation, it shows that as many as 87 respondents or $33.3 \%$ stated that it was excellent. The excellent assessment was 94 respondents or $36.0 \%$, and the assessment was quite fair as many as 57 respondents or as much as $21.9 \%$, and the assessment was not fair as many as 23 respondents or $8,8 \%$. Thus it can be concluded that individual employee attention to customers is exemplary.

Empathy represents caring, individualised attention of the Islamic bank to its customers [34]. This dimension is the profiles of Islamic banks' staff, which can offer customised attention to individual customers. It is beneficial for Islamic banks to build intimacy between its staffs and customers. Empathy has been proved as a substantial dimension of service quality in Islamic banking that results in customers satisfaction [6;37; 39].

\subsection{Promotion}

\subsubsection{Sharia Banks Carry Out Attractive Promotional Activities}

Promotional strategies carried out by banks greatly influence the increase in the number of customers. Promotions carried out by Islamic banks must be attractive so that customers are interested in saving at Islamic banks. Based on the research, the results of the respondents' assessment were 139 respondents or $53.2 \%$ who stated very good, 102 respondents or $39.1 \%$ said that they were right, said that they were quite good by $6.9 \%$ or 18 respondents, and stated that they were not good as many as two respondents or 0 , $8 \%$.

[44] echoed this sentiment and also suggested that Islamic banks should not only consider their business just to fulfill the religious obligations of Muslims, but more significantly as a business that is always seeking to win new customers at the same time retaining existing customers [22]. Therefore, to meet new competitive challenges, Islamic Banks must develop their competencies in customer-relation management, lead management, cross-selling and retention. The strategic endgame for Shariah-compliant, Islamic banks in this context is clear, i.e. customer retention and product saturation (or cross-selling). To achieve this, and to successfully penetrate a new customer segment, companies must invest heavily in understanding the existing customers [21]. This viewpoint is echoed by [13] who argue that Islamic banks should not rely solely on the religious factor as a strategy to attract more consumers, but should emphasize efficient service and should look into situational factors that will determine their level of competitiveness in the future. To extend products into 
new customer segments, conventional banks usually develop three strategies; expanding market presence, franchising products to other distribution channels, and developing aggressive marketing campaigns [21]. Likewise, [27] stress the significance of new marketing and promotional strategies for Islamic banks. They uphold that, in an extremely competitive field, the marketing strategy is critical since Islamic banks not only operate in an environment where service quality and financial returns are perceived as the essential criteria from customers' viewpoint, but they must also compete with conventional banks, that are generally regarded as having more experience and expertise in the field. Moreover, findings of, [27] also suggest that the Islamic banks have to give increasing attention to measuring marketing's effectiveness and customer satisfaction.

\subsubsection{Socialization through print and} electronic media can increase customer knowledge about Islamic savings products

Advances in technology make it easier for Islamic banks to promote more to the public. Apart from aiming at increasing the attractiveness of new customers, promotions carried out through socialization through print, and electronic media provide information to the public about its products, especially Islamic savings products. Based on the data tabulation of the frequency of customers who stated excellent some $23.0 \%$ or 60 respondents, customers who stated good were 152 respondents or $58.2 \%$. Those who stated quite good were 37 respondents or $14.2 \%$ and stated that they were not as good as 12 respondents or $4.6 \%$. Thus, it can be concluded that Islamic banks' socialization through print and electronic media can increase customer knowledge.

The results showed that advertising has the greatest impact on the demand for deposit in Islamic banks. The effect of the other items on the demand for deposit in Islamic banks was average. Although, promotional mix activities can be beneficial in terms of social and economic progression by encouraging healthy competition, however, through the lens of an Islamic marketer, these activities should not encourage wasting or overspending of resources [14].

\subsubsection{Profits Received By Customers Following Promotions Conducted By Islamic Banks}

Promotional activities that aim to attract prospective customers, Islamic banks must be honest and correct in delivering information. This is intended so that there is a balance between the benefits obtained in the promotion with the reality that will be obtained after becoming a customer. The importance of honesty and suitability during promotions will be the key to customer satisfaction. Based on the data tabulation of the frequency of customers who stated very good as many as $34.1 \%$ or 89 respondents, respondents who answered either were 127 or $48.6 \%$, who answered quite well were 40 respondents or $15.3 \%$, and those who answered unfavorably were five respondents or $2 \%$.

[15] assert that Islamic marketing is a process and strategy (Hikmah) of fulfilling needs through Halal (Tayyibat) products and services, with the mutual consent and welfare (Falah) of both parties (i.e. buyers and sellers) for the purpose of achieving material and spiritual well-being in this world and the hereafter. Moreover, Hassan [28] argues that since satisfaction is an important component of the total package of value required by customers; therefore, Islamic banks can use a segment of satisfied customers in its promotional materials to attract new customers.

\subsection{Profit Loss Sharing}

The sharing of business results between the bank as a manager and the customer is based on an agreement between the two parties. Based on the management results, profit-sharing is very different from the concept of interest applied in conventional economic systems. This is the main attraction for the Chinese community to save in Islamic banks.

- Profit sharing system provides convenience in saving

Based on the tabulation of the frequency data, the number of respondents who stated very good was 45 respondents or $17.2 \%$, as many as 138 respondents or $52.9 \%$ said that they were right, then 70 respondents or $26.8 \%$ stated that they were quite good and eight respondents or $3.1 \%$ who said it was not good. Thus it can be concluded that the Sharia Bank, with the profitsharing system, has provided the convenience of saving for its customers.

Mudharabah and musharakah are the products of financing using contract of profit-loss sharing. The indirect impact is forecasted to able to provide the effect of relationship between marketabilities and profitabilities. The area of thought of stewardship is based on trust that humans have duties and responsibilities for the world and religion teaches justice and truth [19].

- Profit sharing system according to the needs of the selected savings product

One of the differences between conventional banks and Islamic banks is the sharing system. A system that cannot be found in conventional banks. 
The purpose of this system is basically to prohibit the interest system, which is generally used by conventional banks. Based on the tabulation of frequency data, the number of respondents who stated very good was 50 respondents or $19.1 \%$. The respondents who stated that they were right were 121 respondents or $46.4 \%$, respondents who stated that were quite good were 83 respondents or $31.8 \%$ and were not good as many as seven respondents or $2.7 \%$. Thus, it can be concluded that the profit-sharing system is by the needs of the savings product chosen by the customer.

\subsubsection{Profits Received By Customers Following Promotions Conducted By Islamic Banks}

Promotional activities that aim to attract prospective customers, Islamic banks must be honest and correct in delivering information. This is intended so that there is a balance between the benefits obtained in the promotion with the reality that will be obtained after becoming a customer. The importance of honesty and suitability during promotions will be the key to customer satisfaction. Based on the data tabulation of the frequency of customers who stated very good as many as $34.1 \%$ or 89 respondents, respondents who answered either were 127 or $48.6 \%$, who answered quite well were 40 respondents or $15.3 \%$, and those who answered unfavorably were five respondents or $2 \%$.

[15] assert that Islamic marketing is a process and strategy (Hikmah) of fulfilling needs through Halal (Tayyibat) products and services, with the mutual consent and welfare (Falah) of both parties (i.e. buyers and sellers) for the purpose of achieving material and spiritual well-being in this world and the hereafter. Moreover, [28] argues that since satisfaction is an important component of the total package of value required by customers; therefore, Islamic banks can use a segment of satisfied customers in its promotional materials to attract new customers.

\subsection{Profit Loss Sharing}

The sharing of business results between the bank as a manager and the customer is based on an agreement between the two parties. Based on the management results, profit-sharing is very different from the concept of interest applied in conventional economic systems. This is the main attraction for the Chinese community to save in Islamic banks.

- Profit sharing system provides convenience in saving

Based on the tabulation of the frequency data, the number of respondents who stated very good was 45 respondents or $17.2 \%$, as many as 138 respondents or
$52.9 \%$ said that they were right, then 70 respondents or $26.8 \%$ stated that they were quite good and eight respondents or $3.1 \%$ who said it was not good. Thus it can be concluded that the Sharia Bank, with the profitsharing system, has provided the convenience of saving for its customers.

Mudharabah and musharakah are the products of financing using contract of profit-loss sharing. The indirect impact is forecasted to able to provide the effect of relationship between marketabilities and profitabilities. The area of thought of stewardship is based on trust that humans have duties and responsibilities for the world and religion teaches justice and truth [19].

- Profit sharing system according to the needs of the selected savings product

One of the differences between conventional banks and Islamic banks is the sharing system. A system that cannot be found in conventional banks. The purpose of this system is basically to prohibit the interest system, which is generally used by conventional banks. Based on the tabulation of frequency data, the number of respondents who stated very good was 50 respondents or $19.1 \%$. The respondents who stated that they were right were 121 respondents or $46.4 \%$, respondents who stated that were quite good were 83 respondents or $31.8 \%$ and were not good as many as seven respondents or $2.7 \%$. Thus, it can be concluded that the profit-sharing system is by the needs of the savings product chosen by the customer.

\section{CONCLUSION}

Based on the results previously described the factors that influence the Chinese community of North Sumatra to save at Islamic banks, the conclusions that can be drawn are:

a) The service quality factor is a factor that influences the Chinese community to save at Islamic Banks in North Sumatra. This is in line with respondents who generally give a fair assessment of all factors related to the quality of Islamic banking services.

b) Promotions carried out by the bank are an essential factor influencing the Chinese community to save at Islamic banks. This is in line with the respondents' assessment to the party's promotions, and the results promoted were by reality.

c) As an ethnic Chinese, North Sumatra is generally interested in the profit-sharing system, so that this 
factor is a factor affecting Chinese customers saving at Islamic banks.

\section{REFERENCES}

[1] Abdullah, A.A., Sidek, R. and Adnan, A.A., "Perception of non-Muslims customers towards Islamic banks in Malaysia", International Journal of Business and Management, Vol. 11 No. 11. 2012

[2] Angelova, B. and Zekiri, J., "Measuring customer satisfaction with service quality using american customer satisfaction model (ACSI model)", International Journal of Academic Research in Business and Social Sciences, Vol. 1 No. 3, 2011, pp. 232-258, doi: 10.6007/ijarbss.v1i2.35.

[3] Akhtar, A. and Zaheer, A., "Service quality dimensions development approach of Islamic banks: a scale development approach", Global Journal of Management and Business Research: A Administration and Management, Vol. 14 No. 5, 2014, pp. 11-19.

[4] Amin, M. and Isa, Z., "An examination of the relationship between service quality perception and customer satisfaction a S.E.M. approach towards Malaysian Islamic banking", International Journal of Islamic and Middle Eastern Finance and Management, Vol. 1 No. 3, 2008, pp. 191-209, doi: $10.1108 / 17538390810901131$.

[5] Armstrong, R.W. and Seng, T.B., "Corporatecustomer satisfaction in the banking industry of Singapore", International Journal of Bank Marketing, Vol. 18 No. 3, 2000, pp. 97-111, doi: https://doi. org/10.1108/02652320010339617.

[6] Al-Tamimi, H.A.H. and Al-Amiri, A., "Analysing service quality in the U.A.E. Islamic banks", Journal of Financial Services Marketing, Vol. 8 No. 2, 2003, pp. 119-132, doi: https://doi.org/10.1057/ palgrave.fsm.4770112.

[7] Ariff, M. "Islamic banking", Asian-Pacific Economic Literature, Vol. 2 No. 2, 1988, pp. 4864 , available at: http://doi.org/https://doi.org/10.1111/j.14678411.1988.tb00200.x

[8] Al-Deehani, T., Karim, R.A.A. and Murinde, V., "The capital structure of Islamic banks under the contractual obligation of profit sharing", International Journal of Theoretical and Applied Finance, Vol. 2 No. 3, 1999, pp. 243-283, available

at:
[9] Ahmed, S. and Rahman, M., "The effects of marketing mix on consumer satisfaction: a literature review from Islamic perspectives", Turkish Journal of Islamic Economics, Vol. 2 No. 1, 2015, pp. 17-30.

[10] Akhtar, A. and Zaheer, A., "Service quality dimensions development approach of Islamic banks: a scale development approach", Global Journal of Management and Business Research: A Administration and Management, Vol. 14 No. 5, 2014, pp. 11-19

[11] Ahmad, A., Saif, I. and Safwan, N., "An empirical investigation of Islamic banking in Pakistan based on perception of service quality", African Journal of Business Management, Vol. 4 No. 6, 2010, pp. 1185-1193

[12] Al-Tamimi, H.A.H. and Al-Amiri, A., "Analysing service quality in the U.A.E. Islamic banks", Journal of Financial Services Marketing, Vol. 8 No. 2, 2003, pp. 119-132, doi: https://doi.org/10.1057/palgrave.fsm.4770112.

[13] Ahmad, N. and Haron, S., "Perceptions of Malaysian corporate customers towards Islamic banking products and services", International Journal of Islamic Financial Services, Vol. 3 No. 4, 2002, pp. 13-29

[14] Abdullah, K. and Ahmad, M.I., "Compliance to Islamic marketing practices among businesses in Malaysia", Journal of Islamic Marketing, Vol. 3, 2010, pp. 286-297

[15] Alom, M.M. and Haque, M.S., "Marketing: an Islamic perspective", World Journal of Social Sciences, Vol. 1 No. 3, 2011, pp. 71-81.

[16] Badan Pusat Statistik, 2020.

[17] Ciptono, W.S. and Sofiyanti, E., "Adapting Islamic banks' carter model: an empirical study in Riau's Syariah banks, Indonesia”, Proceeding PESAT (Psikologi, Ekonomi, Sastra, Arsitek and Sipil), 2, 2007, pp. 120-127.

[18] Charles, V. and Kumar, M., "Satisficing data envelopment analysis: an application to SERVQUAL efficiency," Measurement, Vol. 51, 2014, pp. 71-80

[19] Cossin, D., Ong, B.H. and Coughlan, S. (2015), "A practical perspective: stewardship fostering responsible long-term wealth creation," Vol. 27 No. 2, pp. 404-431, available at www.imd.org/ global assets/board.../stewardship_2015.pdf (accessed April 12, 2018) http://doi.org/10.1142/S0219024999000157 
[20] DeMoranville, C.W., and Bienstock, C.C., "Question order effects in measuring service quality," International Journal of Research in Marketing, Vol. 20 No. 3, 2003, pp. 217-231, DOI: 10.1016/S0167- 8116(03)00034-X.

[21] Divanna, J. and Sreih, A., A New Financial Dawn: The Rise of Islamic Finance, Leonardo and Francis Press Ltd. 2009.

[22] Dusuki, AW.. and Abdullah, N.I., "Why do Malaysian customers patronize Islamic banks?" International Journal of Bank Marketing, Vol. 25 No. 3, 2007, pp. 142-160

[23]Erol, C., Kaynak, E. and El-Bdour, R., "Conventional and Islamic banks: patronage behavior of Jordanian customers," International Journal of Bank Marketing, Vol. 8 No. 4, 1990, pp. 25-35.

[24] Fazlan, S. and Mohammad, A., "The efficiency of Islamic banks: empirical evidence from the MENA and Asian countries Islamic banking sectors", Paper presented at the Fifth International Islamic Finance Conference, 3-4th September, Kuala Lumpur. 2007.

[25] Fararah, F.S. and Al-Swidi, A.K., "The role of the perceived benefits on the relationship between service quality and customer satisfaction: a study on the Islamic microfinance and S.M.E.s in Yemen using P.L.S. approach," Asian Social Science, Vol. 9 No. 10, 2013, pp. 18-36, doi: 10.5539/ass.v9n10p18

[26] Gulf Times, "Islamic finance industry assets surpass 2tn-mark", available at: www.gulf-times. $\mathrm{com} /$ story/.../Islamic-finance-industry-assetssurpass-2tn-mark, 2018.

[27] Haron, S. and Azmi, W., "Marketing strategy of Islamic banks: a lesson from Malaysia", Journal of Islamic Banking and Finance, January-March 2006. 2005.

[28] Hassan, A., Chachi, A., and Abdul Latiff, S., "Islamic marketing ethics and its impact on customer satisfaction in the Islamic banking industry," Journal of King Abdulaziz UniversityIslamic Economics, Vol. 21 No. 1, pp. 27-46. International Organization of Securities Commissions (IOSCO) (2004), "Islamic capital market fact-finding report, July 2004", available at www.iasplus.com/resource/ioscoislamiccapitalma rkets. Pdf (accessed February 22, 2011).

[29] Iqbal, M. and Molyneux, P., "Thirty years of Islamic banking," History, Performance and
Prospects, Bankhistorisches Archiv, Vol. 32 No. 2, 2006, p. 155.

[30] Janahi, M.A. and Almubarak, M., "The impact of customer service quality on customer satisfaction in Islamic banking," Journal of Islamic Marketing, Vol. 8 No. 4, 2015, pp. 595-604, DOI: https://doi.org/10.1108/JIMA-07-2015-0049

[31] Kishada, Z.M.E. and Wahab, N.A., "Factors affecting customer loyalty in Islamic banking: Evidence from Malaysian banks", International Journal of Business and Social Science, Vol. 4 No. 7, 2013, pp. 264-273

[32] Misbach, I. and Hadiwidjojo, D., "Islamic bank service quality and trust: Study on islamic bank in makassar Indonesia", International Journal of Business and Management, Vol. 8 No. 5, 2013, pp. 48-61, doi: 10.5539/ijbm.v8n5p48.

[33] Osman, I., Ali, H., Zainuddin, A., Rashid, W.E.W. and Jusoff, K., "Customers satisfaction in malaysian islamic banking", International Journal of Economics and Finance, Vol. 1 No. 1, 2009, pp. 197, doi: 10.5539/ijef.v1n1p197.

[34] Othman, A. and Owen, L., "Adopting and measuring customer service quality (S.Q.) in Islamic banks: a case study in Kuwait finance house," International Journal of Islamic Financial Services, Vol. 3 No. 1, 2001, pp. 1-26

[35] Otoritas Jasa Keuangan, 2020

[36] Parasuraman, A., Zeithaml, V.A. and Malhotra, A., "E-S-QUAL: a multiple-Item Scale for assessing electronic service quality," Journal of Service Research, Vol. 7 No. 3, 2005, pp. 1-21, DOI: $10.1177 / 1094670504271156$.

[37] Qureshi, M.I., Khan, A., and Zaman, K., "Structural investigation of service quality in conventional and Islamic banking in Pakistan," International Review of Management and Marketing, Vol. 2 No. 2, 2012, pp. 99-105.

[38] Ramdhani, M.A., Ramdhani, A. and Kurniati, D.M., "The influence of service quality toward customer satisfaction of Islamic sharia bank," Australian Journal of Basic and Applied Sciences, Vol. 5 No. 9, 2011, pp. 1099-1104.

[39] Rehman, A.A., "Customer satisfaction and service quality in Islamic banking: a comparative study in Pakistan, United Arab Emirates, and the United Kingdom," Qualitative Research in Financial Markets, Vol. 4 Nos 2/3, 2012, pp. 165-175, DOI: $10.1108 / 17554171211252501$. 
[40] Shafie, S., Azmi, W.N.W., and Haron, S., "Adopting and measuring customer service quality (S.Q.) in Islamic banks: a case study in Bank Islam Malaysia Berhad", Journal of Muamalat and Islamic Finance Research, Vol. 1 No. 1, 2004, pp. $1-12$.

[41] Sugiyono. Metode Penelitian Pendidikan (Pendekatan Kuantitatif, Kualitatif dan R\&D). Penerbit CV. Alfabeta: Bandung. 2015.

[42] Ullah, H., "Shari'ah compliance in Islamic banking an empirical study on selected Islamic banks in Bangladesh," International Journal of Islamic and Middle Eastern Finance and Management, Vol. 7 No. 2, 2014, pp. 182-199, DOI: 10.1108/IMEFM06-2012-0051

[43] Wajdi Dusuki, A. and Irwani Abdullah, N., "Why do Malaysian customers patronize Islamic banks?", International Journal of Bank Marketing, Vol. 25 No. 3, 2007, pp. 142-160.

[44] Wilson, R., "Marketing strategies for Islamic financial products," New Horizon, Vol. 39, 1995, pp. 7-9.

[45] Yoo, D.K. and Park, J.A., "Perceived service quality: Analyzing relationships among employees, customers, and financial performance," International Journal of Quality and Reliability Management, Vol. 24 No. 9, 2007, pp. 908-926, DOI: 10.1108/02656710710826180. 